\title{
The Differential Choice Of Chaebol In Earnings Management
}

\author{
Youngeun Hong, Ph.D., Andong National University, South Korea; \\ Taewoo Kim, Ph. D., University of Massachusetts Lowell, USA \\ Jongkook Park, Ph. D., Yeungnam University, South Korea
}

\begin{abstract}
This study examines the methods of the differential choice of Korean "chaebol" in earnings management. Consistent with our prediction, we find a negative association between chaebols' ownership and accrual-based earnings management, whereas there is no clear difference between chaebols' ownership and real-based earnings management. Furthermore, we find evidence that chaebols exhibit a strongly positive relationship with overproduction-based real activities manipulation, indicating that chaebols prefer overproduction as a method of real earnings management. From additional analyses, we also find that abnormal cash flow from operations is negatively associated with suspect chaebol firm-years that just met zero.
\end{abstract}

Keywords: Earnings Management; Chaebol; Corporate Governance

\section{INTRODUCTION}

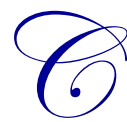

EOs manage their company's earnings using given authorities in order to meet the needs of various management strategies. Schipper (1989) defines earnings management as "a purposeful intervention in the external financial reporting process, with the intent of obtaining some private gain". This definition views accounting numbers as information, and incorporates within it management of any of the components of earnings in terms of the related measurements and disclosures that are included in the financial reporting process. Schipper observes that a natural extension of the definition would further include earnings management "accomplished by timing investment or financing decisions to alter reported earnings, or some subset of it."

Traditionally, research on earnings management has focused on the adjustment of accrual using the change of the accounting method, but recent research has focused more on earnings management through examining the actual activities of companies that can directly affect cash flow. Discretionary accruals that have been used as a method of earnings management cannot be free from the surveillance of financial regulators, and can thus be litigation risks. (Gonzalo and Hemmen, 2010). Furthermore, the reversal process of discretionary accruals does not generally fully support the needs of CEOs. CEOs have therefore sought other methods by which they can supplement or replace discretionary accruals in earnings management. Recent studies (e.g., Barton, 2001; Lin et al., 2006; Zang, 2012) have reported on cases wherein earnings management through real activities and earnings management using discretionary accruals were used simultaneously, or those in which only earnings management through real activities was used ${ }^{1}$. While real earnings management has the advantage of improving short-term profits, it has the correspondent negative effect of decreasing long-term firm value (Graham et al., 2005; Gunny,

\footnotetext{
1 'Real activities manipulation is defined as management actions that deviate from normal business practices, undertaken with the primary objective of meeting certain thresholds' is the definition by Roychowdhury (2006) in a recent article on earnings management.

${ }^{2}$ For this reason, the Korean government annually identifies the thirty largest business groups and publishes a list of their affiliates under the "Monopoly Regulation and Fair Trade Act" to block any anticompetitive behaviors. The act defines the chaebol's affiliates as those where "either more than $30 \%$ of whose issued shares are owned by one person, his relatives, or a company controlled by him, or whose management such as appointing its officers is substantially affected".

${ }^{3}$ Chaebols were started in the 1960s during President Park Chung Hee's military dictatorship administration (1961-1979). In the 1970s Korean economic growth had been explosive. Making use of the government's heavy and chemical industries (HCIs) drive, large companies in Korea were able to develop into conglomerate groups and evolved into chaebols. Throughout the 1980s and 1990s, chaebols' dominance in the Korean 
2005). It can be shown that earnings management through real activities has three core aspects, namely short-term sales increase through price discount and relief of credit condition, decrease of the cost of goods sold through an increase of production, and a reduction of discretionary expenditure (Roychowdhury, 2006). In terms of their longterm negative effects, price discount and lenient credit terms, compared to the sales under normal credit terms and price, will decrease operating cash flow, and may also decrease the sales of the next period and brand power in the long-term. The decrease of the cost of goods via increases in production leads to the increase of production costs. This can not only reduce cash flows given the sales level, but also cause obsolescence risks and the increase of inventory costs in the long-term. Finally, the reduction of discretionary expenditures such as R\&D, advertisement, and training can result in reduction of brand power, weakening of product development potential, and outflow of core-human sources, which will ultimately lower the value of enterprises.

Thus, CEOs' decisions related to earnings management have to be based on a tempered judgment of the realities of their company and the risks involved.

This paper therefore takes as its topic an analysis of the types of earnings managed by the chaebol, a sui generis business type which can be found exclusively in Asia, which play a uniquely important role in the Korean market. Joh (2002) argues that Korean chaebols are "the groups of businesses which are grown under the support of the governments and they are based on the family relationship". Chaebols are generally managed and owned by their founders, and have a system of centralized authoritarian rule in terms of their corporate governance and overall firm management. The chaebol have monopolistic status in the Korean economy through their diversification and vertical integration strategies. Furthermore, the chaebol maximize the mobilization of external capitals through circular equity investment and cross debts guarantee, and increase their size using internal transactions among interrelated enterprises $^{2}$.

Therefore, chaebol can show distinctive behavior in earnings management due to their strong situation as per motivation and business opportunities, relative to non-chaebol companies. Moreover, Guan and Pourjalali (2010) argue that earnings management can be affected by the cultural values which are differentiated from each country. While chaebol is the business type that is solely observed in Asia, especially Korea, less research examined that the relationship between chaebol and earnings management in terms of particular methods. In this research, we analyze the economic environments where Korean chaebols are situated and assess the chaebols' particular methods of conducting earnings management. Considering the reality that chaebols are more severely audited than other companies, we assume that chaebols are more likely to depend on earnings management through real activities due to its lack of negative ramifications which could impact on trust and public opinion.

To test our hypothesis that chaebols are more likely to choose real earnings management than nonchaebols do, we examine both types of earnings management, that is, accrual-based and real earnings management. Adopting the cross sectional Jones (1991) model, we estimate the proxy for accrual-based earnings management. Following Roychowdhury (2006) and Cohen and Zarowin (2010), we measure aggregate metrics as well as single measures of real earnings management.

Our sample is constructed from firms active in the Korean Stock Exchanges (KSE) during the period 20012010, and consists of 5,238 firm-year observations obtained from the Korean Information Service Value database.

Based on the aggregate metrics for earnings management, we find the positive (negative) association between chaebols and real-based (accrual-based) earnings management. Using single measures of real-based earnings management, next, we find that overproduction-based earnings management has a significantly positive relationship with chaebols. Additionally, we find that abnormal cash flows from operations is negatively associated with suspect chaebol firm-years that just met zero. In sum, our findings show that the chaebol have more incentives to manage earnings through real activities even at the cost of negative effects on firm values.

\footnotetext{
${ }^{2}$ For this reason, the Korean government annually identifies the thirty largest business groups and publishes a list of their affiliates under the "Monopoly Regulation and Fair Trade Act" to block any anticompetitive behaviors. The act defines the chaebol's affiliates as those where "either more than $30 \%$ of whose issued shares are owned by one person, his relatives, or a company controlled by him, or whose management such as appointing its officers is substantially affected".
} 
Our study contributes to the literature by providing some implications for future researchers and regulators. As the first study of investigating the relationship between chaebols and real-base earnings management, our findings suggest potentially fruitful lines of enquiry for researchers into how managers manage earnings under the corporate governance. For regulators, our findings provide evidence that variety of methods can be involved in chaebols' earnings management.

The paper consists of the following sections: section two summarizes previous research findings and the theoretical backgrounds of earnings management. Section three sets a research hypothesis and suggests research models. Section four provides analysis results and section five forms a conclusion and discussion of findings.

\section{BACKGROUND AND LITERATURE REVIEW}

\section{Chaebol (Korean Business Groups)}

Business groups are generally defined as collections of formally independent firms that are under shared common administrative and financial controls, owned by families, trusts or foundations. Business groups are globally prevalent, e.g., conglomerates in the Western hemisphere, "keiretsu" in Japan, "grupos economicos" in South American countries, "business houses" in India, and, as this paper discusses, "chaebol" in Korea (Chang, 2006; Granovetter, 1994; Ghemawat and Khanna, 1998; Kester, 1992; Kim, 2009). The chaebol, who play a crucial economic role in Korea, were started in the 1960s and grew to become the engine of government-led economic development plans for the nation ${ }^{3}$.

Chang and Choi (1988) have noted that chaebols follow a multidivisional organizational structure, under which individual affiliated companies function as operating divisions. Cross-shareholding in this context enables a few individuals to tightly control what are nominally (and legally) independent companies. Chaebols typically have staff organizations, often referred to as the chairman's office, the corporate planning office, or the secretarial office. Since chaebol-affiliated companies are legally independent, their performance is shaped by two sets of factors: firstly various forms of intragroup business transactions and secondly the sharing of resources between affiliates.

Chaebols whose member firms are mostly in related businesses may prefer a vertical structure that can allow for vertical integration between upstream and downstream firms, which will provide a higher level of operational efficiency (Chang, 2003). As is typical in a multidivisional structure, a chaebol pools funds generated from affiliated companies and reallocates them in the order of priority set by the group headquarters ${ }^{4}$. Crosssubsidization occurs "when a multi-product firm prices one good at below average cost and makes up for the losses through revenues collected from the sales of other goods that are priced above the average cost" (Viscusi, Vernon, and Harrington, 1992). Such pricing behavior is evidently not consistent with profit maximization or welfare maximization for individual product lines but is consistent with maximizing the overall benefit to a multi-product firm or to a society (Posner, 1971). Likewise, it does not make economic sense for individual affiliates to support poorly performing affiliates, but from the overall group perspective there is the benefit of maximizing total profits. On the individual level, however, it is true that unprofitable firms benefit and profitable firms suffer from crosssubsidization. The most common way that business groups carry out cross-subsidization is by manipulating transfer prices in terms of internal transactions such as loans, debt guarantees, equity investment, and internal business

\footnotetext{
${ }^{3}$ Chaebols were started in the 1960s during President Park Chung Hee's military dictatorship administration (1961-1979). In the 1970s Korean economic growth had been explosive. Making use of the government's heavy and chemical industries (HCIs) drive, large companies in Korea were able to develop into conglomerate groups and evolved into chaebols. Throughout the 1980s and 1990s, chaebols' dominance in the Korean economy was further strengthened. Chaebols have now grown to be 'too big to fail' and too large to stay under the government's discretionary control. In 1997, South Korea faced a moratorium crisis, which forced Korean government to ask the IMF for an emergency bailout loan; the IMF made the provision of assistance conditional on the reform of the way in which the Korean economy and chaebols were managed. Chaebols were largely blamed for the crisis, giving rise to debate about their potential "dismantlement". Alongside the IMF/IBRD recommendations, the Kim Dae Jung government (1998-2003) carried out a wide range of economic reforms including chaebol reforms (Yoo, 1999; Kim, Cha, and Song, 2002; Joh, 2002).

${ }^{4}$ In the Samsung Group, for instance, the main manufacturing firms, such as Samsung Electronics, Samsung Heavy Industries, and Samsung Chemical, are integrated upstream, with their smaller affiliates providing raw materials and intermediate goods and services. These affiliates include Samsung Electro Devices, Samsung Electro Mechanics, and Samsung Corning. The Samsung Corporation, a general trading company, serves as the export window to overseas markets, thus offering other manufacturing affiliates the means for downstream integration.
} 
trade $^{5}$. Figure 1 below shows the major internal transaction flow of Samsung, which is a good representative of Korean chaebols. If we examine this transaction flow, we can see that the internal transactions between the core interrelated enterprises of Samsung, e.g., Samsung Electronics and Samsung SDI, Samsung Electronics and Samsung Electro-Mechanics. The structure of this flow implies that a vertically integrated chaebol, unlike nonchaebol companies, can easily manage earnings through real activities.

Figure 1. Conceptual Diagram of Chaebol Structure and Functioning

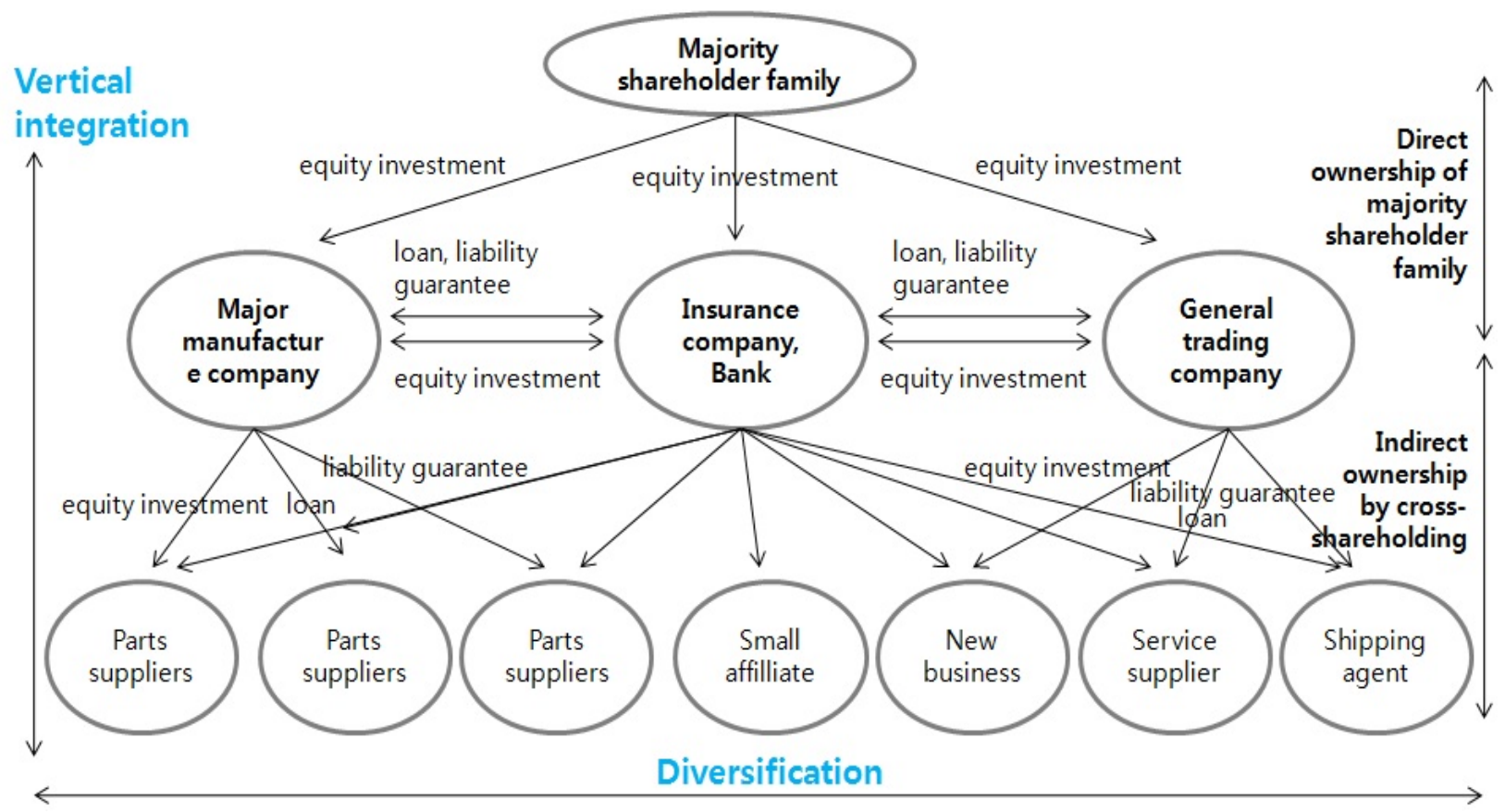

They also can provide a controlling shareholder with the opportunity to diversify investment risk through a portfolio of business lines, to minimize the capital requirement needed to secure control over his group, and to enjoy the private benefit of control (Chang, 2006) ${ }^{6}$. This issue becomes an important factor in forming the characteristics of chaebol. As shown below in Figure 2, the chaebol continue to promote vertical integration and diversification, in such a way that this is an essential part of their functioning.

\footnotetext{
${ }^{5}$ There is a famous case of intragroup business transaction in the Glovis case, one of the biggest groups in Hyundai Motors. When February 2001, the chairman and his son founded a logistics company, Glovis, at a cost of 25 hundred million won. After that the Glovis have been made a monopolizing business in the producing or obtaining include products of assembly, a shipping of steel products, delivering and a part of distributions. According to the Fair Trade Commission Republic of Korea, Glovis had taken 3 trillion won between creation and 2006 from intragroup transaction with four other companies. Because of these transactions, Glovis had made incredible profits relative to the time it had existed. Since the end of 2005, Glovis became a listed company. The chairman and his son received enormous capital benefits.

${ }^{6}$ The emergence of chaebols in Korea was strongly influenced by two factors. Firstly, the market imperfections faced by Korean firms increased transaction costs and encouraged firms to pursue internalization (Khanna and Palepu, 1997). Korea suffered from Japanese colonization and the subsequent Korean War. Because various components of business infrastructures were simply nonexistent at this time, postwar entrepreneurs in Korea had to rely on internal markets to acquire the necessary inputs for their businesses, and business groups found diversification attractive and vertical integration necessary. Secondly, the aggressive, export-oriented development policy of the government provided various supports and subsidies to business groups, further distorting the market mechanism and thereby inducing more expansion (Cole and Park, 1983). Such inducements convinced business groups to pursue diversification that was in line with the government's industrial policy. Shaped by market imperfections and government interventions, the Korean business groups have become both extremely diversified and highly integrated (Chang and Hong, 2000).
} 
Figure 2. Internal Transaction Flow Diagram of Samsung

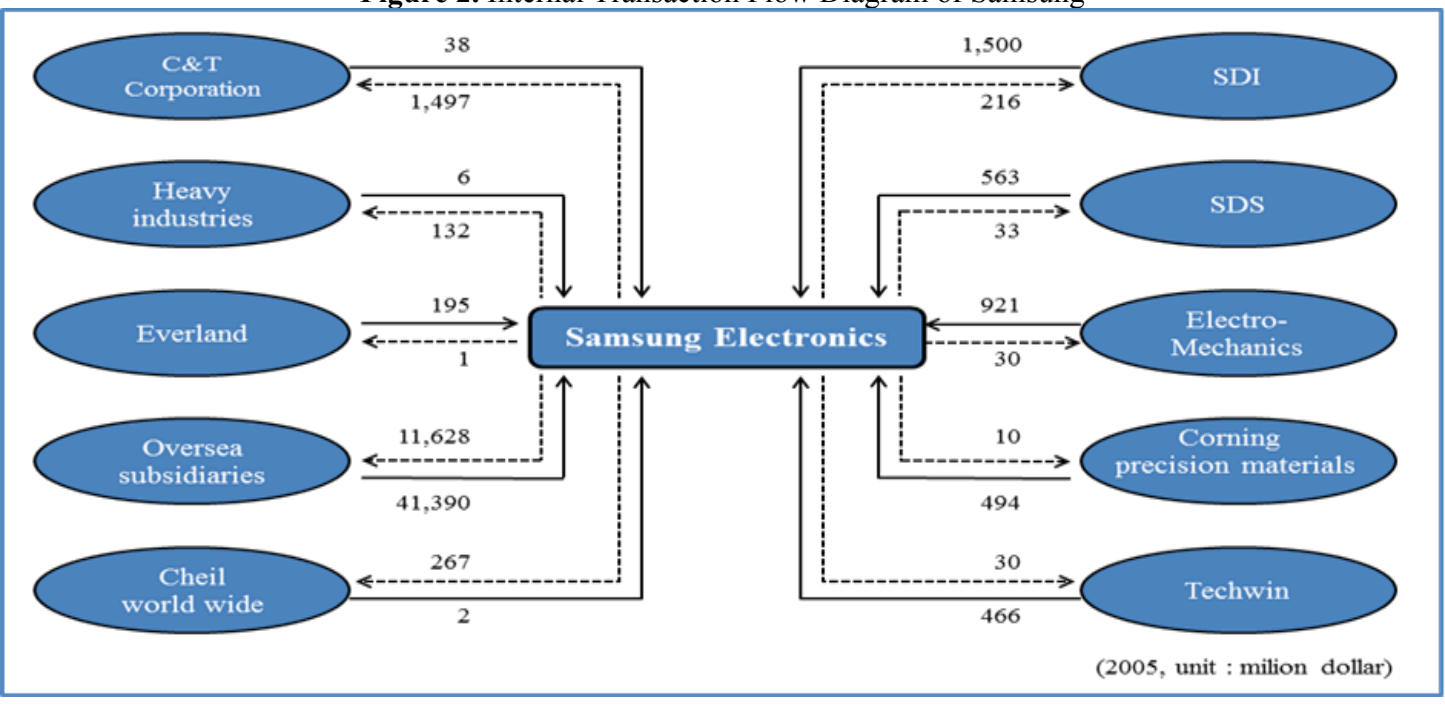

\section{Real- Based Earnings Management}

Defining as "disclosure management in the sense of a purposeful intervention in the external financial reporting process, with intent of obtaining some private gain", Shipper (1989) classifies earnings management into two forms, accrual-based and real earnings management, where 'accrual-based' earnings are managed by changing accounting methods within GAAP without any effect on substantial flow of resources, and 'real' earnings are managed by timing investment, financing, or production decisions affecting the flow of resources. While earnings management literature traditionally focuses on accrual adjustments (i.e., the former earnings management by choosing accounting methods), the recent focus on earnings management has been on real activities affecting cash flows of firms.

Roychowdhury (2006) investigates the way in which real earnings management is conducted through three key methods: e.g., 1) sales manipulation by price discounts and relaxing credit terms, 2) lowering COGS through overproduction, and 3) curtailment of discretionary expenditures. These three methods have damaging effects in the long term on firm value, despite the fact that current earnings may be temporarily ameliorated by these activities, i.e., firm values can be damaged from the reduction in brand loyalty, weakened capabilities of product development, and brain drains.

Yet recent literature suggests that managers do not solely rely on accrual-based earnings management, but rather use real activities for earnings management despite the risk of negative effects on firm values (Barton, 2001; Lin et al., 2006; Zang, 2012). According to survey results from Bruns and Merchant (1990) and Graham et al. (2005), firms in fact seem to prefer real earnings management to accrual-based earnings management.

There are two probable reasons why real earnings management is preferred even despite having known negative effects in the long term. Firstly, accrual-based management can be more closely audited and regulated, when compared with real decision making in terms of price and production. That is, because audits are only performed to confirm whether the reported earnings of firms comply with GAAP, it is difficult for auditors or regulators either to find evidence of real earnings management or to impose penalties in the event of discover. Cohen et al. (2008) document that accrual-based earnings management has decreased, while real earnings management has increased since the Sarbanes-Oxley Act (SOX) was enforced, and interpret from this that managers now choose more complicated methods of earnings management, which external auditors or investors may struggle to detect. Choi et al. (2009) find that there is no discernible market reaction to firms which avoided reporting negative earnings by employing real earnings management. Considering this, in combination with the fact that real earnings management is harder to detect, we can infer that managers are relatively more liable to use real earnings management as a method of overcoming the limits of accrual-based earnings management to achieve targets. 
Secondly, depending solely on accrual-based earnings management would cause managers to take too high a level of risk. That is, because it is problematic to adjust earnings at the end of fiscal year through real activities for earnings management, reported earnings will not meet or beat the target earnings if the shortage for the target earnings is not covered by accrual-based earnings management in the presence of the gap between the reported and target earnings (Roychowdhury, 2006).

\section{HYPOTHESIS DEVELOPMENT AND RESEARCH DESIGN}

\section{The Differential Choices of Chaebol in Earnings Management}

A secondary reason for which the chaebol are likely to prefer earnings management through real activities is that such companies tend to become easily enmeshed in political processes. The Fair Trade Commission (FTC) of Korea monitors and supervises chaebols through "Online Provision of Enterprise Information" in order to control and regulate them. External auditors can also improve the level of general trust in chaebol, which are strongly dependent on the financial statements of information users. Thus, considering the reality that chaebols are more severely audited than other companies, there is further reason that they should prefer earnings management through real activities due to its lack of negative ramifications which could impact on trust and public opinion.

In the main, it may not always be straight-forward for companies to conduct real earnings management if there is a dearth of realistic opportunities to practice this. However for chaebols this is non-problematic in that they will invariably have more opportunities and possibilities to participate in earnings management through real activities due to their vertical integration and diversified business structure.

This can be best understood and clarified by connecting the three methods of real earnings management with the vertical integration and the diversified structure of chaebols.

Compared to non-chaebol companies, chaebols can effectively reduce the cost of goods sold through the increase of production and sales using vertical integration, i.e., through the internal transactions of product sales and purchase. That is, non-chaebol companies have to temporarily increase sales using lenient credit terms and price discounts, but this may lead to the decrease of brand power and sales in the next financial period and ultimately cause a negative effect on the firm's value. The chaebol, however, can improve profit not through the price discount or the lenient credit terms, but through internal transactions, which will not cause negative effects to the firm's value. To reduce the cost of goods sold and fixed costs per unit, a company needs to increase production. And to increase the production, more raw materials and parts need to be supplied in the manufacturing processes. Nonchaebols can be exposed at this point to the dangers of unstable changes to raw material prices and supply prices, resulting in their having difficulties in securing necessary raw materials and parts. However, chaebols can reduce the trade cost using internal transactions (Williamson, 1975), and can thus secure the raw materials and parts smoothly. Considering this, we can predict that chaebols are likely to be able to manage earnings management through real activities like production increase more easily than non-chaebol companies.

Finally, through irrelevant diversification, which is one of the representative characteristics of chaebols, technology, branding, intangible resources, and human resources can be shared, and this can create a synergistic effect. Furthermore, chaebols can reduce their discretionary expenses more effectively than non-chaebols. That is, non-chaebol companies can improve profit of the current period by reducing discretionary expenditures like their $\mathrm{R} \& \mathrm{D}$, advertisement, and training costs. However, this may damage the firm's final value due to a lowering of brand power, weakening of the product's development potential, and the outflow and loss of core human resources. Chaebols, by contrast, can establish a R\&D center at corporation level and thereby provide cutting edge information technology to all their interrelated enterprises. This information sharing will reduce the R\&D expenses of the individual interrelated enterprises of the chaebol, with no weakening their potential for product development.

Further to this, all the interrelated enterprises of a chaebol share a brand name. Therefore, the brand power of the chaebol will not be severely reduced when an individual enterprise or affiliate of the chaebol reduces its advertisement expenses. 
Finally, because the chaebol's companies share their human resources through co-hiring and co-training programs, they are able to minimize negative effects which could be caused by the reduction of training costs. Therefore, we can once again show there is a strong incentive for chaebols to prefer earnings management through real activities, given that for them, unlike non-chaebols, the associated risks of the practices can be easily minimized. We thus set this paper's hypothesis based on predictions as follows:

Hypothesis: Unlike non-chaebol companies, chaebols prefer earnings management through real activities to the earnings management using discretionary accruals

Table 1. Hypothesis Development

\begin{tabular}{|c|c|c|c|c|}
\hline & Business Activity & Negative Effect & Chaebol's Opportunities & $\begin{array}{c}\text { Differential } \\
\text { Burden }\end{array}$ \\
\hline $\begin{array}{l}\text { Accrual-Based } \\
\text { Earnings } \\
\text { Management }\end{array}$ & $\begin{array}{l}\text { Discretionary } \\
\text { Accounting } \\
\text { Choices }\end{array}$ & $\begin{array}{l}\text { - Increase in monitoring by } \\
\text { financial regulatory bodies } \\
\text { - Increase in litigation risks } \\
\text { - Reversal effect }\end{array}$ & $\begin{array}{l}\text { - Political costs hypothesis } \\
\text { - OPNI (Online Provision of } \\
\text { Enterprise Information) }\end{array}$ & $\begin{array}{l}\text { chaebol }>\text { other } \\
\text { company } \\
\text { chaebol = other } \\
\text { company }\end{array}$ \\
\hline \multirow[t]{3}{*}{$\begin{array}{l}\text { Real-Based } \\
\text { Earnings } \\
\text { Management }\end{array}$} & $\begin{array}{l}\text { Sales } \\
\text { Manipulation }\end{array}$ & $\begin{array}{l}\text { - Decrease in cash flow from } \\
\text { operation or long-term sales } \\
\text { - Damage to brand power }\end{array}$ & \multirow{2}{*}{$\begin{array}{l}\text { Vertically Integrated Structure } \\
\text { - Increasing sales and } \\
\text { decreasing transaction costs } \\
\text { based on internal transaction } \\
\text { within chaebol firms }\end{array}$} & \multirow[t]{2}{*}{$\begin{array}{l}\text { chaebol }<\text { other } \\
\text { company }\end{array}$} \\
\hline & Overproduction & $\begin{array}{l}\text { - Increase in inventory costs } \\
\text { or inventory obsolescence } \\
\text { risk }\end{array}$ & & \\
\hline & $\begin{array}{l}\text { Reduction of } \\
\text { Discretionary } \\
\text { Expenditures }\end{array}$ & $\begin{array}{l}\text { - Damage to brand power } \\
\text { - Depression in R\&D } \\
\text { - Outflow of core human } \\
\text { resources }\end{array}$ & $\begin{array}{l}\text { Diversified Business Structure } \\
\text { - Sharing of brand } \\
\text { - Sharing of technology using } \\
\text { the R\&D center } \\
\text { - Sharing human resources } \\
\text { using the human resources } \\
\text { development center }\end{array}$ & $\begin{array}{l}\text { chaebol < other } \\
\text { company }\end{array}$ \\
\hline
\end{tabular}

Hypothesis: Unlike non-chaebol companies, chaebols prefer earnings management through real activities to the earnings management using discretionary accruals

\section{Measurement of Accrual and Real-based Earnings Management}

To test the prediction that chaebols prefer and use real earnings management more than non-chaebols do, we examine the two types of earnings management: accrual-based earnings management and real earnings management. Accrual-based earnings management involves generally accepted accounting principles (GAAP), and consists of making accounting choices that try to "obscure" or "mask" a firm's true economic performance (Dechow and Skinner, 2000). Real earnings management, by contrast, occurs when managers undertake practical actions that change the timing or structuring of an operation, investment, and/or financing transaction in an effort with the desired aim of influencing output.

\section{Measurement of Accrual-based Earnings Management}

We adopt performance-matched discretionary accruals that use a proxy for accrual-based earnings management. We include the ROA (return on asset) variable as shown in Kothari et al. (2005), using a modified Jones (1991) model $^{7}$ as follows:

\footnotetext{
${ }^{7}$ The modified Jones (1991) model as suggested by Dechow et al.(1995) is estimated as follows: $\frac{T A_{i t}}{A S S E T_{i t-1}}=\alpha_{1} \frac{1}{A_{i t-1}}+\alpha_{2} \frac{\Delta R E V_{i t}}{A_{i t-1}}+\alpha_{3} \frac{P P E_{i t}}{A_{i t-1}}+\varepsilon_{i t}$, where $\mathrm{i}$ indexes firms, $\mathrm{t}$ indexes time, $T A_{i t}$ equals Net Income minus Cash Flow from Operations, $R E V_{i t}$ is the changes in sales revenues from the preceding year and $P P E_{i t}$ is gross value of property, plant, and equipment. All the variables used here are scaled by total assets at the beginning of the period. They use the estimated $\hat{\alpha}_{1}, \hat{\alpha}_{2}$, and $\widehat{\alpha}_{3}$ to calculate the nondiscretionay accruals for our sample firms:
} 


$$
\frac{T A_{i t}}{A_{i t-1}}=\gamma_{0}+\gamma_{1}\left(\frac{1}{A_{i t-1}}\right)+\gamma_{2}\left(\frac{\left.\Delta R E V_{i t}-\Delta A R_{i t}\right)}{A_{i t-1}}\right)+\gamma_{3}\left(\frac{P P E_{i t}}{A_{i t-1}}\right)+\gamma_{4} R O A_{i t(\text { or it }-1)}+\varepsilon_{i t}
$$

where $\mathrm{i}$ indexes firms, $\mathrm{t}$ indexes time, $T A_{i t}$ equals the Net Income minus Cash Flow from Operations, and $R E V_{i t}$ is the changes in sales revenues from the preceding year. $A R_{i t}$ is the change in receivables from the preceding year and $P P E_{i t}$ is gross value of property, plant, and equipment combined. All the variables used here are scaled by total assets at the beginning of the period. shown below:

We use the estimated $\hat{\gamma}_{1}, \hat{\gamma}_{2}, \hat{\gamma}_{3}$ and $\hat{\gamma}_{4}$ to calculate the non-discretionary accruals for our sample firms as

$$
N D A_{i t}=\hat{\gamma}_{1} \frac{1}{i t-1}+\hat{\gamma}_{2} \frac{\left(\Delta R E V_{i t}-\Delta A R_{i t}\right)}{A_{i t-1}}+\hat{\gamma}_{3} \frac{P P E_{i t}}{A_{i t-1}}+\hat{\gamma}_{4} R O A_{i t}
$$

From this, we can derive discretionary accruals as follows:

$$
D A_{i t}=\left(\frac{T A_{i t}}{\text { Asset }_{i t-1}}\right)-N D A_{i t}
$$

Measurement of Real- based Earnings Management

Following from Roychowdhury (2006), we measure real earnings management as being abnormal levels of discretionary expenses, productions cost, and cash flows from operations (CFO), using the model developed by Dechow et al. (1998).

We focus on the three manipulation methods and their effects on the above three variables. Firstly, managers cut discretionary expenditures such as R\&D, advertising, and selling, and general and administrative expenditures (SG\&A) to achieve their earnings targets. We can estimate abnormal discretionary expenditures as the residuals from the following cross-sectional regression estimated by year and two digit industries:

$$
\frac{\text { Discretionary Expenditure }_{i t}}{\mathrm{~A}_{\mathrm{t}-1}}=\alpha_{1} \frac{1}{A_{i t-1}}+\beta\left(\frac{\text { Sales }_{t}}{A_{i t-1}}\right)+\varepsilon_{t}
$$
SG\&A.

We here measure discretionary expenditure as the sum of R\&D expenses, advertising expenses, and

Secondly, managers try to increase earnings by allocating a larger portion of fixed overhead costs to overproduction units in their inventory. This implies that the reported cost of goods sold (COGS) should be lower.

$$
\frac{\operatorname{COGS}_{t}}{A_{t-1}}=\alpha_{0}+\alpha_{1} \frac{1}{A_{t-1}}+\beta \frac{\text { Sales }_{t}}{A_{t-1}}+\varepsilon_{t}
$$

Again following Dechow et al. (1998), we estimate the model for 'normal' inventory growth using the following regression:

$$
\frac{\Delta I N V_{t}}{A_{t-1}}=\alpha_{0}+\alpha_{1} \frac{1}{A_{t-1}}+\beta_{1} \frac{\Delta \text { Sales }_{t}}{A_{t-1}}+\beta_{2} \frac{\Delta \text { Sales }_{t}}{A_{t-1}}+\varepsilon_{t}
$$

$\Delta I N V_{i t}$ is here the change in inventory in period t. We define production costs as the sum of cost of goods sold and change in inventory. Using (5) and (6), we can estimate normal production costs from the following industry-year regression.

$N D A_{i t}=\hat{\alpha}_{1} \frac{1}{i t-1}+\widehat{\alpha}_{2} \frac{\left(\triangle R E V_{i t}-\triangle A R_{i t}\right)}{A_{i t-1}}+\hat{\alpha}_{3} \frac{P P E_{i t}}{A_{i t-1}}$, where $A R_{i t}$ is the change in receivables from the preceding year. Thus, They can derive discretionary accruals as follows: $D A_{i t}=\left(\frac{T A_{i t}}{\text { Asset }_{i t-1}}\right)-N D A_{i t}$. 


$$
\frac{{\text { Production } \text { Cost }_{t}}_{A_{t-1}}}{A} \alpha_{0}+\alpha_{1} \frac{1}{A_{t-1}}+\beta_{1} \frac{\text { Sales }_{t}}{A_{t-1}}+\beta_{2} \frac{\Delta \text { Sales }_{t}}{A_{i t-1}}+\beta_{3}\left(\frac{\Delta \text { Sales }_{t-1}}{A_{t-1}}\right)+\varepsilon_{t}
$$

Finally, managers can accelerate their company's sales or generate additional unsustainable sales by offering more discounts to customers or more lenient credit terms. However, these real transaction management actions will result in bringing down the amount of cash collected per dollar of sales in the current period. This is expected to lead to a lower current-period CFO than what would be considered normal relative to sales level.

$$
\frac{\mathrm{CFO}_{t}}{A_{t-1}}=\alpha_{0}+\alpha_{1} \frac{1}{A_{t-1}}+\beta_{1} \frac{\text { Sales }_{t}}{A_{t-1}}+\beta_{2} \frac{\Delta \text { Sales }_{t}}{A_{i t-1}}+\varepsilon_{t}
$$

where $A_{t}$ is the total assets at the end of period $t$, Sales $t$ is the sales during period $t$ and change in sales is the difference between the period $t$ and the period $t$ - 1 . For every firm-year, abnormal cash flow from operations is the actual CFO minus the "normal" CFO calculated using estimated coefficients from the corresponding industry year model and the firm-year's sales and lagged assets.

As in Roychowdhury (2006), it is expected that real earnings management activities will lead to lower cash flow form operation (abnormal CFO, ACFO), lower discretionary expenses (abnormal discretionary expenses, ADE), and higher production costs (abnormal production costs, APC) than what would be considered normative relative to the sales level. We use these three variables as proxies for real earnings management.

Consistent with Cohen and Zarowin (2010), we additionally take into account two combined variables that can capture the total effects of real earnings management. The first of these variables is the sum of the abnormal production costs and abnormal discretionary expenses multiplied by negative one (REM (1)). The second is the sum of the abnormal cash flows from operations and the abnormal discretionary expenses, both multiplied by negative one (REM (2)). The higher these aggregate measures (i.e., REM (1) and REM (2)) are found to be, the more likely it is the firm engaged in real earnings management activities.

\section{Estimation Models}

After including all of the control variables, to test our hypothesis, we estimate the following ordinary least squares (OLS) regression using a broad sample of firms. Of the equations below, (9) tests the association between real earnings management and the chaebol dummy, and (10) tests the accrual-based earnings management and chaebol dummy. To be consistent with our hypothesis, the coefficient of the chaebol dummy will have to be significantly positive in equation (9), and the coefficient of the chaebol dummy will have to be significantly negative in equation (10).

$$
\begin{aligned}
& \text { REM } M_{i t}=\beta_{0}+\beta_{1} \text { Chaebol }_{i t}+\beta_{2} \text { BIG }_{i t}+\beta_{3} \text { SIZE }_{i t}+\beta_{4} L E V_{i t}+\beta_{5} N I_{i t} \\
& +\beta_{6} \text { MTB }_{i t}+\beta_{7} \text { Loss }_{i t}+\Sigma \text { Year }+\Sigma I n d+\varepsilon_{i t} \\
& \begin{array}{l}
\text { AEM } \\
\text { it }
\end{array}=\beta_{0}+\beta_{1} \text { Chaebol }_{i t}+\beta_{2} \text { BIG }_{i t}+\beta_{3} \text { SIZE }_{i t}+\beta_{4} L E V_{i t}+\beta_{5} N I_{i t} \\
& +\beta_{6} \text { MTB }_{i t}+\beta_{7} \text { Loss }_{i t}+\Sigma Y e a r+\Sigma I n d+\varepsilon_{i t}
\end{aligned}
$$

where, respectively, REM and AEM denote the measure of the real earnings management and accrual-based earnings management. As previously indicated this paper employs an advanced set of measures for calculating realbased earnings management, namely the Roychowdhury model. The measurement of accrual-based earnings management uses the performance-adjusted modified Jones (1991) model (i.e., the modified Jones (1991) model with $\mathrm{ROA}_{t}$ and the modified Jones model (1991) with ROA $\mathrm{t}_{-1}$.) (Kothari et al., 2005). The addition of ROA $\mathrm{or}$ $\mathrm{ROA}_{\mathrm{t}-1}$ is one method suggested by Kothari et al. as a way of controlling for the performance component of discretionary accruals. Due to data limitations, this study is unable to use the more powerful approach of performance-matching that is recommended in Kothari et al.'s work.

Chaebol is our test variable, which is categorical and is assigned as " 1 " if a firm is a chaebol and " 0 " otherwise. 
Additional control variables are included in the regression models to control for other factors known to influence earnings management. We include control variables for auditors in the above regression to examine whether the earnings management activities of firms audited by large-scale audit firms are different from the rest of the sample firms. Note that we make no claim that differences in the earnings management activities (if any) of these firms are the direct result of the monitoring activities of the audit firms, since there could be a self-selection by certain types of firms in their selection of big audit firms. In addition, to the extent that audit firms specialize in specific industries, levels of earnings management are likely to vary across industries and the audit firm dummies may also control for industry characteristics (Cohen et al., 2008).

The last five control variables used in this study relate to the firm's financial statement variables. The incentive of managers' discretionary accounting choices may systematically differ according to firm size. To control for the potentially mixed effects that may arise from differences in firm sizes, in our sample measurement of the $\log$ value of total asset (SIZE), is included in the regression. Leverage is measured as the ratio of total liabilities to total asset at the beginning of the year (LEV). NI is measured as the net income scaled by total assets at the beginning of the year. Other control variables include the firms' growth prospect, proxied by ratio of market value to book value (MTB). Loss is here measured as a categorical variable, assigned as "1" if the firm reported a loss and "0" otherwise.

Industry dummies and year dummies are included to control for industry-wide and time-wide effects that could potentially explain some variation in firms' earnings management behavior across different industries and time periods.

\section{Sample Selection and Data}

The sample is constructed from firms active in the Korean Stock Exchanges (KSE) during 2001 to 2010. We extract accounting data from the Korean Information Service Value database (hereafter KisValue).

We select firm-years that satisfy the following criteria: (1) a non-financial firm; (2) the fiscal year-end of the firm is December; and (3) financial statement data, which is required for the computation of the main variables, is available from KisValue. Financial firms are excluded because their inclusion may give rise to problems, in that their earnings management may be limited or differ systematically from firms in other industries due to inherent differences in functioning. The exclusion of financial firms from our sample is thus designed to increase the internal validity of our study.

To alleviate potential measurement error problems, observations that fall within one percent of the highest or lowest values of the dependent variables are deleted. All of the control variables are also winsorized at the $1^{\text {st }}$ or $99^{\text {th }}$ percentile in order to reduce the influence of extreme values.

This process yields a final sample of 5,239 firm-year observations from KSE-listed firms operational between 2001 and 2010.

\section{EMPIRICAL RESULTS}

\section{Descriptive Statistics and Correlations}

Descriptive statistics are shown below in Table 2. This shows that the mean of the chaebols' accrual-based earnings management usage (AEM) is smaller than that of non-chaebols. We can thus assume that chaebols are less likely to depend on accrual-based earnings management using discretionary accrual than non-chaebols. By contrast, there is no clear difference between chaebols and non-chaebols in terms of APC, ADE, and REM (1) in that the differences are not statistically significant. Chaebols exhibit on average higher ACFO and lower REM (2) respectively. This implies that the interpretation of the analysis of CFO-based real earnings management should be careful not because chaebols less rely on real earnings management, but because such differences may arise from dissimilar cash holding policies between chaebols and non-chaebol firms. In the control variables, chaebols' variables except Loss are larger than those of non-chaebols. 
Table 2. Descriptive Statistics on Selected Variables

\begin{tabular}{|c|c|c|c|c|c|c|c|c|c|c|c|}
\hline \multirow{2}{*}{ Variables } & \multicolumn{5}{|c|}{ Chaebol $(n=1,220)$} & \multicolumn{5}{|c|}{ Non-Chaebol $(n=4,019)$} & \multirow[t]{2}{*}{ t-stat } \\
\hline & Mean & STD & Min & Median & Max & Mean & STD & Min & Median & Max & \\
\hline ACFO & 0.009 & 0.080 & -0.445 & 0.008 & 0.442 & -0.004 & 0.087 & -0.787 & -0.004 & 0.687 & $5.03 * * *$ \\
\hline APC & 0.004 & 0.149 & -0.668 & 0.016 & 0.422 & 0.002 & 0.142 & -0.708 & 0.010 & 0.613 & $0.45^{* * *}$ \\
\hline $\mathrm{ADE}$ & 0.001 & 0.082 & -0.253 & -0.006 & 0.884 & -0.003 & 0.072 & -0.490 & -0.009 & 0.853 & 1.34 \\
\hline $\operatorname{REM}(1)$ & 0.003 & 0.200 & -1.365 & 0.020 & 0.505 & 0.004 & 0.174 & -1.490 & 0.015 & 0.653 & $-0.21 * * *$ \\
\hline $\operatorname{REM}(2)$ & -0.010 & 0.124 & -1.096 & 0.001 & 0.501 & 0.007 & 0.116 & -0.851 & 0.010 & 0.843 & $-4.25^{* * *}$ \\
\hline AEM & -0.008 & 0.072 & -0.408 & -0.006 & 0.304 & 0.003 & 0.080 & -0.466 & 0.003 & 0.821 & $-4.75^{* * *}$ \\
\hline BIG & 0.809 & 0.392 & 0.000 & 1.000 & 1.000 & 0.502 & 0.500 & 0.000 & 1.000 & 1.000 & $22.36^{* * *}$ \\
\hline SIZE & 28.019 & 1.487 & 24.013 & 28.039 & 30.686 & 25.891 & 1.060 & 23.762 & 25.804 & 30.686 & $46.53^{* * *}$ \\
\hline LEV & 0.509 & 0.182 & 0.086 & 0.526 & 0.948 & 0.447 & 0.195 & 0.086 & 0.447 & 0.948 & $10.31^{* * *}$ \\
\hline NI & 0.046 & 0.073 & -0.333 & 0.047 & 0.278 & 0.034 & 0.089 & -0.333 & 0.037 & 0.278 & $4.59^{* * *}$ \\
\hline МТВ & 1.279 & 1.094 & 0.104 & 0.953 & 5.727 & 0.897 & 0.871 & 0.104 & 0.631 & 5.727 & $11.16^{* * *}$ \\
\hline Loss & 0.139 & 0.346 & 0.000 & 0.000 & 1.000 & 0.194 & 0.395 & 0.000 & 0.000 & 1.000 & $-4.65 * * *$ \\
\hline
\end{tabular}

Note: All of the variables are defined in Appendix. ${ }^{* * *},{ }^{* *}$, and $*$ denote the significance of $t$-statistic at the $0.01,0.05$, and 0.10 levels, respectively.

Table 3 presents correlations among related variables. The correlations between the chaebol dummy (Chaebol) and the two methods of earnings management (i.e., REM (2) and AEM) reveal negative and statistically significant correlations, while the correlation between Chaebol and the CFO-based REM measurement (ACFO) is significantly positive, which implies that the components of REM as seen in chaebols' systematic functioning must be investigated more carefully. Consistent with the characteristics of REM measurement, the correlations between REM and each component of REM are (-), (+), and (-), respectively. The correlation coefficient between CFO-based REM (ACFO) and accrual-based EM (AEM) is strongly negative (-77\%), which is consistent with the results of prior studies. Consistent with Roychowdhury (2006), overproduction-based REM (APC) and discretionary expenditure-based REM (ADE) exhibit a significantly negative correlation (-29\%). In addition, the negative correlation (-12\%) between abnormal production costs (APC) and abnormal cash flows from operations (ACFO) is consistent with the theory that overproduction is likely to have a negative effect on abnormal cash flow from operations.

Table 3. Correlations

\begin{tabular}{|c|c|c|c|c|c|c|c|c|c|c|c|c|}
\hline & Chaebol & ACFO & APC & ADE & REM(1) & REM(2) & AEM & BIG & SIZE & LEV & NI & MTB \\
\hline ACFO & 0.066 & 1.000 & & & & & & & & & & \\
\hline APC & 0.006 & -0.123 & 1.000 & & & & & & & & & \\
\hline $\mathrm{ADE}$ & 0.020 & 0.088 & -0.296 & 1.000 & & & & & & & & \\
\hline REM(1) & -0.003 & -0.134 & 0.919 & -0.649 & 1.000 & & & & & & & \\
\hline REM(2) & -0.061 & -0.779 & 0.275 & -0.692 & 0.505 & 1.000 & & & & & & \\
\hline AEM & -0.062 & -0.779 & 0.081 & -0.053 & 0.087 & 0.598 & 1.000 & & & & & \\
\hline $\mathrm{BIG}$ & 0.262 & 0.049 & -0.034 & 0.073 & -0.057 & -0.081 & -0.042 & 1.000 & & & & \\
\hline SIZE & 0.608 & 0.078 & -0.025 & 0.063 & -0.045 & -0.096 & -0.059 & 0.306 & 1.000 & & & \\
\hline LEV & 0.136 & -0.186 & 0.117 & -0.039 & 0.109 & 0.159 & 0.066 & 0.065 & 0.173 & 1.000 & & \\
\hline NI & 0.057 & 0.296 & -0.034 & 0.099 & -0.068 & -0.276 & 0.004 & 0.076 & 0.165 & -0.324 & 1.000 & \\
\hline MTB & 0.171 & 0.107 & -0.073 & 0.149 & -0.119 & -0.171 & -0.070 & 0.073 & 0.126 & 0.141 & 0.116 & 1.000 \\
\hline Loss & -0.060 & -0.195 & -0.004 & -0.061 & 0.022 & 0.180 & 0.014 & -0.037 & -0.154 & 0.261 & -0.689 & 0.002 \\
\hline
\end{tabular}

Note: Correlation coefficients in bold are significant at the $1 \%$ level or $5 \%$ level.

\section{Results for Testing Hypothesis}

Table 4 presents the results of Equations (9) and (10). Our study hypothesis predicts a positive coefficient on Chaebol in (9) would exist. Consistent with this, the coefficient $\left(\beta_{1}\right)$ is positive and significantly different from zero $(p<0.01)$ for REM (1). For REM (2), however, the coefficient is negative and statistically insignificant. Our hypothesis predicts that the coefficient would be negative in (10). Consistent with this, $\beta_{1}$ is -0.0059 and significant at $10 \%$ level. We also find that REM variables are negatively correlated with BIG and MTB, and positively correlated with LEV. 
Table 4. Regression Results for Testing Hypothesis

$R E M(1 \text { or } 2)_{i t}=\beta_{0}+\beta_{1}$ Chaebol $_{i t}+\beta_{2} B I G_{i t}+\beta_{3} S I Z E_{i t}+\beta_{4} L E V_{i t}+\beta_{5} N I_{i t}$

$+\beta_{6} M T B_{i t}+\beta_{7}$ Loss $_{i t}+\Sigma$ Year $+\Sigma$ Ind $+\varepsilon_{i t}$

$A E M_{i t}=\beta_{0}+\beta_{1}$ Chaebol $_{i t}+\beta_{2} B I G_{i t}+\beta_{3} S I Z E_{i t}+\beta_{4} L E V_{i t}+\beta_{5} N I_{i t}$

$+\beta_{6}$ MTB $B_{i t}+\beta_{7}$ Loss $_{i t}+\Sigma$ Year $+\sum$ Ind $+\varepsilon_{i t}$

\begin{tabular}{|c|c|c|c|c|c|c|}
\hline \multirow{2}{*}{ Variables } & \multicolumn{2}{|c|}{ REM(1) } & \multicolumn{2}{|c|}{ REM(2) } & \multicolumn{2}{|c|}{ AEM } \\
\hline & Estimate & t-stat & Estimate & t-stat & Estimate & t-stat \\
\hline Intercept & $0.097 * *$ & 1.16 & $-0.051 * * *$ & -0.93 & $0.027 * * *$ & 0.68 \\
\hline Chaebol & $0.023^{* *}$ & 3.11 & $-0.005 * * *$ & -1.09 & $-0.006^{* *}$ & -1.70 \\
\hline BIG & $-0.012 * *$ & -2.31 & $-0.008 *$ & -2.37 & $-0.003 * * *$ & -1.12 \\
\hline SIZE & $-0.005^{*}$ & -2.27 & $-0.001 * * *$ & -0.33 & $-0.002 * *$ & -1.68 \\
\hline LEV & $0.117^{* *}$ & 8.21 & $0.086^{* *}$ & 9.19 & $0.051 * *$ & 7.57 \\
\hline NI & $-0.032 * *$ & -0.83 & $-0.303 * *$ & -11.77 & $0.079 * *$ & 4.28 \\
\hline MTB & $-0.031 * *$ & -10.99 & $-0.025 * *$ & -13.40 & $-0.008 * *$ & -5.63 \\
\hline Loss & $-0.016^{*}$ & -1.87 & $-0.002 * * *$ & -0.37 & 0.006 *** & 1.47 \\
\hline $\mathrm{N}$ & \multicolumn{2}{|c|}{5,239} & \multicolumn{2}{|c|}{5,239} & \multicolumn{2}{|c|}{5,239} \\
\hline Adjusted $\mathrm{R}^{2}$ & \multicolumn{2}{|c|}{0.184} & \multicolumn{2}{|c|}{0.179} & \multicolumn{2}{|c|}{0.037} \\
\hline F-value $(\mathrm{Pr}>\mathrm{F})$ & \multicolumn{2}{|c|}{$19.78^{* *}$} & \multicolumn{2}{|c|}{19.10 ** } & \multicolumn{2}{|c|}{$4.15 * *$} \\
\hline
\end{tabular}

Note: All of the variables are defined in Appendix. ${ }^{* *},{ }^{* *}$, and $*$ denote the significance of $t$-statistic at the $0.01,0.05$, and

0.10 levels, respectively.

The results for the real earnings management variables are inconsistent across the two combined variables REM (1) and REM (2). This finding indicates that the three individual variables underlying REM (1) and REM (2) may have different implications for earnings, which may in turn dilute any results that use these aggregated measures (see: Cohen and Zarowin, 2010). Hence, we use the three individual real earnings management proxies (abnormal CFO, abnormal production cost, and abnormal discretionary expenditure). Table 5 presents results for the analysis of REM component-separated regressions.

Table 5. Regression Results for Testing Hypothesis

(REM component-separated regressions)

\begin{tabular}{|c|c|c|c|c|c|c|}
\hline \multicolumn{7}{|c|}{$\begin{array}{l}\text { REM }(A C F O \text { or } A P C \text { or } A D E)_{i t}=\beta_{0}+\beta_{1} \text { Chaebol }_{i t}+\beta_{2} B I G_{i t}+\beta_{3} S I Z E_{i t}+\beta_{4} L E V_{i t}+\beta_{5} N I_{i t} \\
\quad+\beta_{6} \text { MTB }_{i t}+\beta_{7} \text { Loss }_{i t}+\Sigma Y e a r+\Sigma I n d+\varepsilon_{i t}\end{array}$} \\
\hline \multirow[t]{2}{*}{ Variables } & \multicolumn{2}{|c|}{$\begin{array}{c}\text { ACFO } \\
\text { (Abnormal CFO) }\end{array}$} & \multicolumn{2}{|c|}{$\begin{array}{c}\text { APC } \\
\text { (Abnormal Production Costs) }\end{array}$} & \multicolumn{2}{|c|}{$\begin{array}{c}\text { ADE } \\
\text { (Abnormal Discretionary Expenses) }\end{array}$} \\
\hline & Estimate & t-stat & Estimate & t-stat & Estimate & t-stat \\
\hline Intercept & $-0.022 * * *$ & -0.53 & $0.200 * *$ & 2.53 & $0.073^{* *}$ & 2.04 \\
\hline Chaebol & $0.010 * *$ & 2.83 & $0.018^{* *}$ & 3.04 & $-0.005 * * *$ & -1.56 \\
\hline BIG & $0.002 * * *$ & 0.68 & $-0.005^{* * *}$ & -1.35 & $0.006^{* *}$ & 2.87 \\
\hline SIZE & $-0.000 * * *$ & -0.12 & $-0.005^{* *}$ & -2.48 & $0.001^{* * *}$ & 0.65 \\
\hline LEV & $-0.071 * *$ & -10.29 & $0.102 * *$ & 8.91 & $-0.015 * *$ & -2.40 \\
\hline NI & $0.252 * *$ & 13.21 & $0.019 * * *$ & 0.59 & $0.051 * *$ & 3.04 \\
\hline MTB & $0.010^{* *}$ & 7.09 & $-0.016^{* *}$ & -6.97 & $0.015^{* *}$ & 12.55 \\
\hline Loss & $0.003 * * *$ & 0.68 & $-0.016 * *$ & -2.43 & $-0.001 * * *$ & -0.21 \\
\hline $\mathrm{N}$ & \multirow{2}{*}{\multicolumn{2}{|c|}{$\begin{array}{l}5,239 \\
0.140\end{array}$}} & \multicolumn{2}{|c|}{5,239} & \multicolumn{2}{|c|}{5.239} \\
\hline Adjusted $\mathrm{R}^{2}$ & & & \multirow{2}{*}{\multicolumn{2}{|c|}{$\begin{array}{c}0.165 \\
17.42 * *\end{array}$}} & \multicolumn{2}{|c|}{0.124} \\
\hline F-value $(\operatorname{Pr}>F)$ & \multicolumn{2}{|c|}{$14.49 * *$} & & & & \\
\hline
\end{tabular}

Note: All of the variables are defined in Appendix. ${ }^{* *},{ }^{* *}$, and $*$ denote the significance of $t$-statistic at the $0.01,0.05$, and 0.10 levels, respectively.

When CFO is measured as REM, the coefficient on Chaebol in the first column is unexpectedly positive and statistically significant. However, the coefficient on Chaebol is, as expected, significantly positive when overproduction is measured as REM, whereas the coefficient on Chaebol in the last column is insignificant when REM is replaced with discretionary expenditures.

From the results of table 5, we can infer that chaebols use overproduction most among the three methods of REM, compared with non-chaebol companies. It can be surmised that chaebols can more benefit from 
overproduction REM than non-chaebols, because chaebols can clear out overproduced goods through intragroup business transactions, even though chaebols report earnings higher through overproduction.

On the other hand, it is relatively less likely, given our findings, that chaebols lower their prices through transactions among subsidiaries. This is shown through the fact that the coefficient on Chaebol is unexpectedly positive with CFO-based REM as a dependent variable. Given this result, there is a possible concern as to whether this result represents some other phenomenon, such as differences in cash holding policies between chaebols and non-chaebol firms. We investigate this issue in additional analyses, as found in the section 4.3 below.

\section{Additional Analyses}

To increase the power of our tests that aim to detect real earnings management, we conduct additional tests using "suspect chaebol firm-years" (Sus_Chaebol). As in Roychowdhury (2006), we identify suspect chaebol firmyear observations with net income scaled by total assets, which is greater than or equal to zero but less than 0.005 , since chaebols during years in the interval of just right of zero are likely to manage their earnings to report income marginally above zero (Burgstahler and Dichev, 1997; Hansen, 2010; McNichols, 2000).

Figure 3 presents a histogram of net income scaled by total assets at the beginning of the year that is constructed with widths of 0.005 for the range -0.075 to +0.075 . It reveals similar patterns to those documented by previous literature, showing a discontinuity in frequency of firm-years around zero earnings.

If suspect chaebol firm-years that report profits just above zero undertake activities that adversely affect their CFO, then the abnormal CFO for these firm-years should be negative compared to the rest of the chaebol sample. Table 6 reports the results of this test, that is, using suspect chaebol firm-years to examine whether abnormal CFO can capture the earnings management activities of chaebols. Consistent with our prediction, abnormal CFO is negatively associated with suspect chaebol firm-years that just meet zero (coefficient -0.0322 , pvalue $<0.01$ ). Specifically, suspect chaebol firm-years have abnormal CFO that is lower on average by $3 \%$ of assets when compared to the rest of our chaebol sample.

Figure 3. Number of Firm Years by Earnings Interval

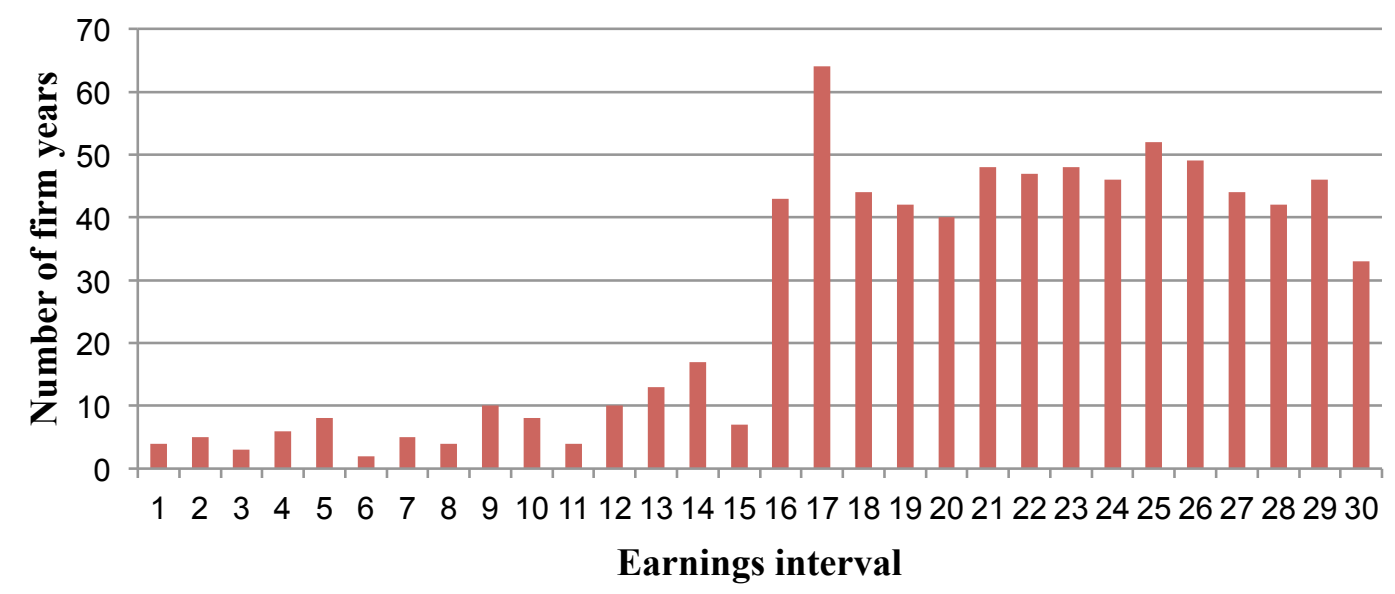

Note: Figure 3 charts the number of firm years by each earnings interval between -0.075 and +0.075 over the 2001 2010 sample period in chaebols, where earnings is defined as net income scaled by total assets. Each interval is the width of 0.005 . The sample is truncated at the two ends and includes 794 observations, including 43 suspect chaebol firm-years. 
Table 6. Comparison of Suspect Interval with Other Intervals in Chaebols

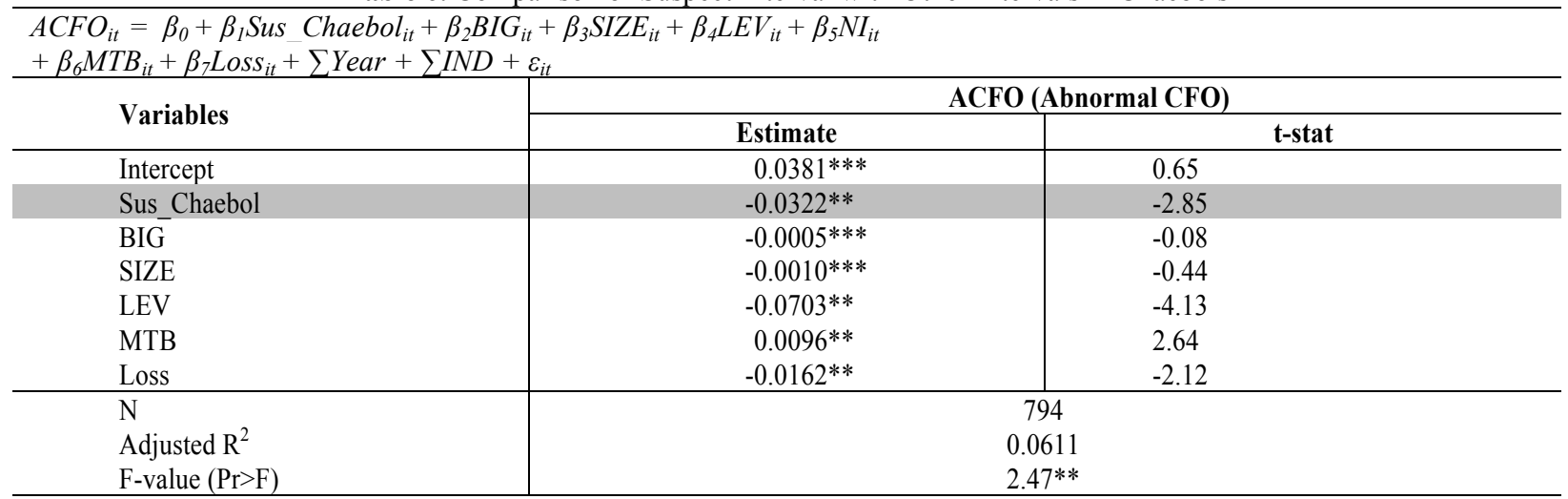

Note: All of the variables are defined in Appendix. ${ }^{* * *},{ }^{* *}$, and ${ }^{*}$ denote the significance of t-statistic at the $0.01,0.05$, and 0.10 levels, respectively.

\section{CONCLUSION}

This study presents empirical evidence that shows how managers choose between AEM and REM. In particular, this study aims to examine the methods used by chaebols to conduct earnings management.

It is hypothesized that chaebols are likely to prefer real-based earnings management due to its being less susceptible to detecting by auditors or regulators and as a result of their public position in Korean society and correspondent political vulnerability. It is shown that chaebols pursue a reduction in the cost of their sales through the increase of production and sales, making use of the vertical integration structure that is inherent to their functioning, to enable the sale of products and internal transaction of purchases. The chaebol will further improve its profit and loss of the current period by minimizing the negative effects of cutting down expenditure on discretionary expenses such as $\mathrm{R} \& \mathrm{D}$, advertising expenses, and training expenses, because the companies which belong to a specific chaebol usually share technology, branding, intangible resources, and human resources through their diversified business structure. This means that chaebols will have enough opportunities to pursue earnings management through real activities.

We can thus predict that the chaebol will prefer earnings management through real activities than earnings management using discretionary accruals.

We find that the coefficient on Chaebol with abnormal production cost-based REM as a dependent variable is positive, whereas the coefficient on Chaebol with AEM as a dependent variable is significantly negative. Considering the trade-off among components of REM, we analyze the relationship between chaebols and each component of REM, and find that that overproduction-based REM has a significantly positive relationship with the chaebol, which implies that chaebols' preferred method of REM is over-production. From the additional analysis of suspect chaebol firm-years, we find that abnormal CFO is negatively associated with suspect chaebol firm-years that just met zero, implying that their CFO is negatively affected by earnings management activities.

Our research findings have some implications for future researchers and regulators. For researchers, our findings suggest potentially fruitful lines of enquiry into how managers use earnings management in corporate governance. For regulators, our findings try to show the variety of chaebols' earnings management methods. Our finding could thus help to widen understanding of regulation needs in this field.

In closing, this study has several limitations and extensions that merit further research. Firstly, given the weakness of the measurement of real earnings management, there is a need to develop more refined models. Secondly, our estimation models use indirect methods to test our hypothesis. To be more robust, future models should be changed to use more direct methods. Secondly, the investigation could be expanded to address chaebols' different behavior in individual economic periods, e.g., before and after the Korean Financial Crisis. 


\section{AUTHOR INFORMATION}

Youngeun Hong ( $1^{\text {st }}$ author), is an Assistant Professor of Department of Accounting at Andong National University, South Korea. She holds a Ph.D. in Management (Accounting Concentration) from Yeungnam University, South Korea (2010). E-mail: yehong@andong.ac.kr

Taewoo Kim is an Assistant Professor of Accounting at University of Massachusetts Lowell. He holds a Ph.D. in Management (Accounting Concentration) from State University of New York at Buffalo (2013). Prior to joining the academia, he worked for Ernst \& Young Korea for several years and he is a Certified Public Accountant of South Korea. E-mail: taewoo_kim@uml.edu

Jongkook Park (corresponding author), is an Associate Professor of School of Business at Yeungnam University, South Korea. He holds a Ph.D. in Management (Accounting Concentration) from Sungkyunkwan University (2005). He joined the Korean Journal of Business Research (ISSN 1226-458X) as editor-in-chief in January of 2015. E-mail: jkpark@ynu.ac.kr

\section{REFERENCES}

Barton, J. (2001). Does the use of financial derivatives affect earnings management decisions? The Accounting Review, 76 (1) 1-26.

Bruns, W. \& Merchant, K. (1990). The dangerous morality of managing earnings. Management Accounting, 72 2225.

Burgstahler, D. \& Dichev, I. (1997). Earnings management to avoid earnings decreases and losses. Journal of Accounting and Economics, 24 (1) 99-126.

Chang, S. (2003). The Financial crisis and transformation of Korean business groups: Rise and fall of chaebols. Cambridge, UK: Cambridge University Press.

Chang, S. (2006). Business groups in East Asia: Financial crisis, restructuring and new growth. Oxford, UK: Oxford University Press.

Chang, S. \& Choi, U. (1988). Strategy, structure and performance of Korean business groups. Journal of Industrial Economics, 37 141-158.

Chang, S. \& Hong, J. (2000). Economic performance of group-affiliated companies in Korea: Intragroup resource sharing and internal business transactions. Academy of Management Journal, 43 429-448.

Choi, M., Kim, J., \& Baik, S. (2009). Earnings management through real operational activities manipulation and market response. Korean Management Review, 38 (5) 1185-1211.

Cohen, D., Dey, A., \& Lys, T. (2008). Real and accrual-based earnings management in pre- and post-Sarbanes Oxley periods. The Accounting Review, 83 (3) 757-787.

Cohen, D. \& Zarowin, P. (2010). Accrual-based and real earnings management activities around seasoned equity offerings. Journal of Accounting and Economics, 50 (1) 2-19.

Cole, D. \& Park, Y. (1983). Financial development in the Republic of Korea 1945-78. Cambridge, MA: Harvard University Press.

Dechow, P., Kothari, S., \& Watts, R. (1998). The relation between earnings and cash flows. Journal of Accounting and Economics, 25 (2) 133-168.

Dechow, P. \& Skinner, D. (2000). Earnings management: Reconciling the views of accounting academics, practitioners and regulators. Accounting Horizons, 14 (2) 235-250.

Dechow, P., Sloan, R., \& Sweeney, A. (1995). Detecting earnings management. The Accounting Review, 70 (2) 193225.

Fisman, R. \& Khanna, T. (1998). Intermediation in global capital markets: the role of business groups. Working Paper, Harvard Business School, Boston.

Ghemawat, P. \& Khanna, T. (1998). The nature of diversified business groups: A research design and two case studies. Journal of Industrial Economics, 46 35-61.

Gonzalo, R. P. \& Hemmen, S. F. (2010). Debt, diversification and earnings management. Journal of Accounting and Public Policy, 29 138-159.

Graham, J., Harvey, C., \& Rajgopal, S. (2005). The economic implications of corporate financial reporting. Journal of Accounting and Economics, 40 3-73. 
Granovetter, M. (1994). Business groups. In Smelser, N. \& Swedberg, R. (Eds.), The handbook of Economic sociology: 453-475. Princeton, NJ: Princeton University Press.

Gunny, K. (2005). What are the consequences of real earnings management? Working paper, University of California, Berkeley.

Hansen, J. C. (2010). The effect of alternative goals on earnings management studies: An earnings benchmark examination. Journal of Accounting and Public Policy, 29 459-480.

Joh, S. (2002). Chaebol reform and structural change in corporate sector. Korea Development Institute.

Jones, J. (1991). Earnings management during import relief investigations. Journal of Accounting Research, 29 193228.

Kester, W. (1992). Industrial groups as systems of contractual governance. Oxford Review of Economic Policy, 8(3) 24-44.

Khanna, T. \& Palepu, K. (1997). Why focused strategies may be wrong for emerging markets. Harvard Business Review, 75 (4) 41-51.

Kim, I., Cha, B., \& Song, C. (2002). Reform, sustainable growth and vulnerability to crisis in Korea. Paper presented to the conference "The Korean Economy: Beyond the Crisis", organized by the Research Center for International Finance, Seoul National University on October 4-5.

Kothari, S., Leone, A., \& Wasley, C. (2005). Performance matched discretionary accrual measures. Journal of Accounting and Economics, 39 (1) 163-197.

Lin, S., Radhakrishnan, S., \& Su, L. (2006). Earnings management and guidance for meeting or beating analysts' earnings forecasts. Working paper, California State University at Frenso.

McNichols, M. (2000). Research design issues in earnings management studies. Journal of Accounting and Public Policy, 19 (4-5) 313-345.

Posner, R. 1971. Taxation by regulation. Bell Journal of Economics, 22-50.

Prencipe, A, Bar-Yosef, S., Mazzola, P., \& Pozza, L. (2011). Income smoothing in family-controlled companies: Evidence from Italy. Corporate Governance: An International Review, 19(6) 529-546.

Roychowdhury, S. (2006). Earnings management through real activities manipulation. Journal of Accounting and Economics, 42 335-370.

Schipper, K. (1989). Commentry on earnings management. Accounting Horizons, 3 91-102.

Viscusi, W., Vernon, J., \& Harrington, J. (1992). Economics of regulation and anti-trust. D.C. Heath and Company, Lexington, MA.

Williamson, D. (1975). Markets and hierarchies. New York, NY: Free Press.

Yoo, S. (1999). Corporate Restructuring in Korea: Policy Issues Before and During the Crisis. Korea Development Institute, Seoul, Korea.

Zang, A. Y. (2012). Evidence on the trade-off between real activities manipulation and accrual-based management. The Accounting Review, 87 (2) 675-703.

Zhao, Y., Chen, K. H., Zhang, Y., \& Davis, M. (2012). Takeover protection and managerial myopia: Evidence from real earnings management. Journal of Accounting and Public Policy, 31 109-135. 


\section{APPENDIX. Variable Definition}

\begin{tabular}{|c|c|}
\hline Var & Definition \\
\hline Chaebol & dummy variable equal to 1 if the year of observation is in Korean large business group. \\
\hline & $\begin{array}{l}=\text { abnormal cash flow from operations which is estimated as the deviations from the predicted values from } \\
\text { the following industry-year regression: } \frac{C F O_{t}}{A_{t-1}}=\alpha_{0}+\alpha_{1} \frac{1}{A_{t-1}}+\beta_{1} \frac{\text { Sales }_{t}}{A_{t-1}}+\beta_{2} \frac{\Delta \text { Sales }_{t}}{A_{i t-1}}+\varepsilon_{t} \text {, where "CFO" is } \\
\text { cash flow from operations and "A" is total assets }\end{array}$ \\
\hline$A P C$ & 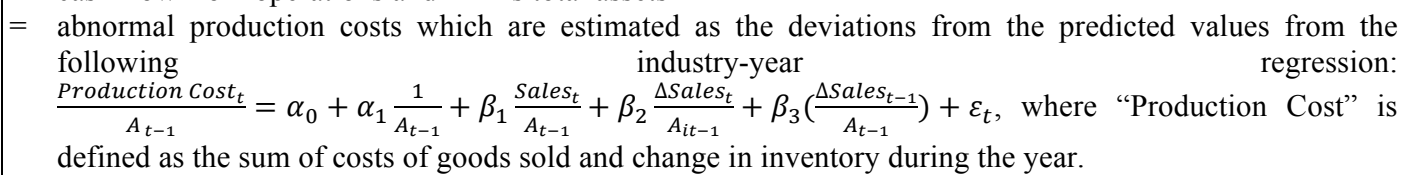 \\
\hline$A D E$ & $\begin{aligned}= & \text { abnormal discretionary expenses which are estimated as the deviations from the predicted values from the } \\
& \text { following industry-year regression: } \frac{\text { Discretionary Expenditure } e_{i t}}{A_{\mathrm{t}-1}}=\alpha_{1} \frac{1}{A_{i t-1}}+\beta\left(\frac{\text { sales }_{t}}{A_{i t-1}}\right)+\varepsilon_{t} \text {; "Discretionary }\end{aligned}$ \\
\hline REI & $\begin{array}{l}\text { Expenditure" is defined as the sum of advertising expenses, R\&D expenses, and selling, general, and } \\
\text { administrative expenditures (SG\&A). } \\
=\text { aggregate measure of real earnings management activities and is calculated as the sum of abnormal } \\
\text { discretionary expenses multiplied by negative one and abnormal production cost. }\end{array}$ \\
\hline$R E M(2)$ & $\begin{aligned}= & \text { agg } \\
& \text { flor }\end{aligned}$ \\
\hline$A E M$ & $\begin{array}{l}\text { ance-adjusted modified Jones (1991) model (the } \\
\text {, 2005). }\end{array}$ \\
\hline$B I G$ & Big 4 auditors, and 0 otherwise. \\
\hline SIZE & $=\log$ \\
\hline$L E V$ & $=$ ratio \\
\hline$N I$ & $=\mathrm{ne}$ \\
\hline$M T B$ & $=\mathrm{gl}_{1}$ \\
\hline Loss & $=$ dummy variable which is equal to 1 if \\
\hline Sus_C & $\begin{aligned}= & \text { dummy variable equal to } 1 \text { if the year of observation is suspect chaebol firm-years that net income scale } \\
& \text { by total assets is greater than or equal to zero but less than } 0.005 \text { (interval } 16 \text { in Figure } 3 \text { ). }\end{aligned}$ \\
\hline
\end{tabular}




\section{NOTES}

